Tropical Journal of Pharmaceutical Research October 2013; 12 (5): 851-856

ISSN: $1596-5996$ (print); 1596-9827 (electronic)

(C) Pharmacotherapy Group, Faculty of Pharmacy, University of Benin, Benin City, 300001 Nigeria.

All rights reserved.

Available online at http://www.tjpr.org

Original Research Article

http://dx.doi.org/10.4314/tjpr.v12i5.28

\title{
A Multifactorial Intervention to Enhance Adherence to Medications and Disease-Related Knowledge in Type 2 Diabetic Patients in Southern Punjab, Pakistan
}

\author{
Abdul Majeed Samtia ${ }^{1^{*}}$, Muhammad Fawad Rasool ${ }^{1}$, Nazar Muhammad Ranjha ${ }^{1}$, \\ Faisal Usman ${ }^{1}$ and Ibrahim Javed ${ }^{1}$ \\ ${ }^{1}$ Faculty of Pharmacy, Bahauddin Zakaryia University, Multan, Pakistan
}

*For correspondence: Email: abdulmajeedsamtia@yahoo.com, Tel: +923336139819

Revised accepted: 17 June 2013

\begin{abstract}
Purpose: To assess the impact of pharmacist-led multifactorial interventions on health parameters, medication adherence, and disease-related knowledge among type 2 diabetic patients in southern Punjab, Pakistan.

Methods: The effect of intervention was evaluated by randomly assigning patients into control group ( $n=$ 170), receiving conventional medical care, and intervention group $(n=178)$, receiving predefined specialized care. The primary outcome of this intervention study was improvement in glycemic control which was assessed by measuring fasting blood glucose and glycosylated haemoglobin (HbA1C) values.

Results: The outcomes obtained clearly show the role of pharmacist counseling in the control of type 2 diabetes while improving fasting blood glucose (FBG) and HbA1c levels, reduction in Body Mass Index (BMI), improvement in disease knowledge as well as reduction in smoking. The intervention significantly reduced BMI and waist circumference by a difference of $1.87(p=0.014)$ and $1.27(p=0.002)$ between control and intervention groups. Glycemic control was significant within the intervention group, as evident by a reduction in fasting blood glucose level $\{-19.26 \mathrm{mg} / \mathrm{dL}(p=0.003)\}$ and $\mathrm{HbA} 1 \mathrm{c}$ level $\{-1.01 \%(p<0.001)\}$ compared to control group. The mean difference in glycemic control between both groups was insignificant but mild reductions were seen in fasting blood glucose $(-11.95 \mathrm{mg} / \mathrm{dL}, p=0.11)$ and HbA1c $(-0.43 \%, p=$ 0.12). A significant increase in disease-related knowledge was seen in the intervention group, compared to the control group which was evident by mean differences in compliance $(p=0.003)$, foot-care $(p<0.001)$ and self-monitoring of blood glucose $(p=0.001)$.

Conclusion: The purpose of study was achieved in that it demonstrates that pharmacists can play a pivotal role in improving glycemic control in diabetic patients and that involvement of pharmacists in diabetic clinics is beneficial to the patients in terms of medication adherence and promotion of healthy lifestyle.
\end{abstract}

Keywords: Diabetes, Intervention, Medication adherence, Glycemic control, BMI, HbA1c

Tropical Journal of Pharmaceutical Research is indexed by Science Citation Index (SciSearch), Scopus, International Pharmaceutical Abstract, Chemical Abstracts, Embase, Index Copernicus, EBSCO, African Index Medicus, JournalSeek, Journal Citation Reports/Science Edition, Directory of Open Access Journals (DOAJ), African Journal Online, Bioline International, Open-J-Gate and Pharmacy Abstracts

\section{INTRODUCTION}

The worldwide rising prevalence of diabetes can be directly related to economic development, ageing population, increasing population, dietary changes, and decrease in physical activity [1]. It is predicted that in 2030 , the number of diabetes patients worldwide will rise to 472 million and $80 \%$ of them will be residents of low and middleincome countries [2].

Medication adherence may be defined as "the extent to which a person's behavior coincides with medical advice" [3]. The rate of non- 
adherence to long-term therapies for chronic illnesses in developed countries is about $50 \%$ and these rates are much lower in developing countries. Adherence to medications among diabetes patients is very poor, and it varies widely in different geographical areas with adherence rates between 36 and $94 \%[4,5]$.

It has been shown that pharmacists' intervention can improve clinical outcomes by improving medications use in outpatients [6]. The complications associated with diabetes can be reduced with the help of disease specific interventions for achieving glycemic control. Data suggest that a large proportion of patients with diabetes have high HbA1c values [7]. The effect of the pharmacist's intervention in diabetes has proven to be effective in lowering fasting blood glucose and $\mathrm{HbA} 1 \mathrm{c}$ values. Improvement in selfmanagement and better knowledge of diabetes was seen with pharmacist led diabetes education program [8].

The overall objective of this study was to assess the impact of pharmacist-led interventions on glycemic control, medication adherence, disease knowledge, and lifestyle modifications among patients with diabetes in Southern Punjab, Pakistan.

\section{METHODS}

\section{Study design}

The method used for this study was based on questionnaire designed to collect information such as gender, age, BMI, waist circumference, smoking history, education, diabetes type, blood pressure (BP), oral hypoglycemic agents used, insulin use, HbA1c level and FBG to access patient condition and awareness of diseaserelated knowledge.

This study design was interventional and carried out for a 5-month period in selected diabetes clinics in southern Punjab (Nishter Hospital Multan and DHQ Hospital Layyah). The study was performed in accordance with the international clinical guidelines and prior written permissions were taken from the patients. The sample population was 500 patients.

\section{Inclusion/exclusion criteria}

Diabetic patients who were receiving an oral hypoglycemic medication from at least last 6 months and were having BMI more than 25 were included in this study. Patients solely on insulin therapy were not included in the study due to lack of knowledge regarding proper insulin administration method and dose calculation.

\section{Patient groups and intervention}

Patients were randomly assigned into control $(n=170)$ and intervention groups $(n=178)$. Patients in the control group received usual medical care. Patients in the intervention group received pre-defined specialized care during the whole study. Five pharmacists were the part of the study team, and all of them had a background in clinical pharmacy and a minimum experience of 3 years in hospital setting. The components of the pre-defined care were:

I. Education of disease including short and long term complications

II. Medication adherence and its effects on glycemic control

III. Education regarding timing of medication use in relation to food

IV. Education regarding dietary restrictions

V. Education regarding sensory changes including foot examination

VI. Role of exercise in achieving glycemic control

VII. Role of self-monitoring of blood glucose in achieving glycemic control

VIII. Education regarding control of $\mathrm{Hb} 1 \mathrm{c}$ values and fasting blood glucose in diabetes patients

IX. Smoking cessation

\section{Outcomes measures}

Patients included in both control and intervention groups were asked to perform fasting blood sugar tests every 4 weeks at $0,4,8,12,16$ and 20 weeks. Patients were asked to test their HbA1c values at the start and at the end of the study. Self-reporting approach was used to assess adherence to medications. Knowledge regarding disease, self-monitoring, and lifestyle modifications were assessed on yes/no basis at the start and end of the study.

\section{Statistical analysis}

Sample size was determined by a standard statistical formula [9] and was found to be 163 in each group. Statistical analysis was performed using statistical software SPSS version 16.0 (SPSS Inc, Chicago, III). A two tailed significance level of 0.05 was used in the study. Independent t-tests and Chi-Square tests were used for. comparing baseline data with group values. Results of the continuous variables between control and intervention groups were analyzed using paired sample t-tests. Independent sample $\mathrm{t}$-tests were used to evaluate mean differences between control and intervention groups from baseline. Evaluation of non-parametric 
responses was done by using Wilcoxon signed ranks test for assessment of differences within each group between time 0 and 20 weeks. Mann-Whitney U-test was used to evaluate mean differences in responses between control and intervention groups.

\section{RESULTS}

Patients visiting various diabetic clinics in Southern Punjab during the period of March, 2011 to May, 2011 meeting the inclusion criteria were selected and assigned randomly into control $(n=170)$ and intervention group $(n=178)$. Almost all the patients included completed the study (control group: 168/170 and intervention group: 174/178). Reasons for dropout were mainly non-affordability of medication and traveling costs to keep hospital appointments. Lack of motivation and one patient died during follow-up. The baseline characteristics of both study groups were similar and are shown in Table 1. Baseline $\mathrm{HbA} 1 \mathrm{c}$ values were available for 97 control group and 108 intervention group patients.

\section{BMI and waist circumference}

Significant reductions from baseline in BMI and waist circumference were seen in the intervention group BMI (-2.46, $\mathrm{P}=0.002)$, waist circumference $(-2.24$ inches, $P<0.001)\}$, Table 2. The reductions were not significant in control group $(-0.59, \mathrm{P}=0.08)$ but $\mathrm{BMl}$ reductions were insignificant $(-0.97$ inches, $P=0.46)$. Mean differences of BMI and waist circumference between control and intervention group were significant $(P=0.0014$ and 0.002$)$, respectively.

\section{Glycemic control}

There was significant reduction in fasting blood glucose and $\mathrm{HbA} 1 \mathrm{c}$ values in the intervention group $(-19.26 \mathrm{mg} / \mathrm{dL}, p=0.003$ and $-1.01 \%, p<$ $0.001)$. Reductions were seen in fasting blood glucose and HbA1c values $(-7.31 \mathrm{mg} / \mathrm{dL}$ and $0.46 \%$ ) in control group but were insignificant ( $p$ $=0.23$ and 0.11 ). Mean differences of fasting blood glucose and HbA1c values between control and intervention group from baseline were not significant $(p=0.116$ and 0.112$)$.

\section{Adherence to medications}

Adherence to medication was assessed by selfreport of the patients in both groups. Improvements in adherence rates were seen in both control and intervention groups. These improvements were significant in intervention group as compared to control group ( $p=0.052$ vs 0.310). Differences between control and intervention groups from baseline were significant $(p=0.003)$.

\section{Disease knowledge and self-care activities}

There was significant improvement in patient's disease knowledge and self-care activities in the intervention group as shown in Table 3 . Intervention group showed improvement regarding knowledge of sensory changes ( $p=$ $0.001)$, foot care $(p=0.012)$, self-monitoring of blood sugar $(p=0.002)$, role of exercise $(p=$ $0.011)$ and dietary restrictions $(p=0.001)$. Mean differences between control and intervention groups from baseline were significant in knowledge regarding sensory changes $(p<$ $0.001)$, self-monitoring of blood sugar and role of exercise $(p<0.001)$.

\section{Smoking cessation}

There was an increase in the percentage of nonsmokers in both groups. The increase in nonsmokers was significant in intervention group ( $p$ $=0.019)$ but was insignificant in control group ( $p$ $=0.564)$. The difference between control and intervention group on smoking rates was not significant $(p=0.491)$.

\section{Baseline characteristics of study groups}

With regard to care in type 2 diabetic patients, it was observed that pharmacist interaction in these patients led to control of blood glucose level. The beneficial role of pharmacist intervention was even more evident with regard to BMI, waist circumference and $\mathrm{HbA} 1 \mathrm{c}$ than for FBG. Similarly, patient compliance significantly increased with pharmacist counseling on a regular basis. This was seen in patients in the intervention group as no progression of disease occurred.

\section{DISCUSSION}

It was found that multifactorial interventions in diabetic patients resulted in improvement in glycemic control which was evident from significant reductions in fasting blood glucose level and $\mathrm{HbA} 1 \mathrm{c}$ values. The role of the pharmacist in the management of diabetes has been established and various studies have been done to prove the effects of pharmacists' intervention on glycemic control [10]. Pharmacist's involvement in the management of diabetic patients with the physician has led to improved glycemic control and lipid levels [11]. It is the need of the time that pharmacist and 
Table 1: Baseline characteristics of study groups

\begin{tabular}{|c|c|c|c|}
\hline \multicolumn{2}{|c|}{ Parameter } & $\begin{array}{c}\text { Control group } \\
(n=170)\end{array}$ & $\begin{array}{c}\text { Intervention group } \\
(n=178)\end{array}$ \\
\hline \multicolumn{4}{|c|}{ Gender (\%) } \\
\hline 0 & Male & 48.2 & 52.8 \\
\hline 0 & Female & 51.2 & 47.2 \\
\hline \multicolumn{4}{|c|}{ Age (years) } \\
\hline 0 & Mean & 42.3 & 46.1 \\
\hline ○ & Range & $21-77$ & $23-74$ \\
\hline \multicolumn{4}{|l|}{ BMI } \\
\hline o & Mean & 32.01 & 31.98 \\
\hline o & Range & $25.3-44.2$ & $25.1-42.7$ \\
\hline \multicolumn{4}{|c|}{ Waist circumference } \\
\hline o & Mean & 37.98 & 35.38 \\
\hline o & Range & $35-57$ & $33-54$ \\
\hline \multicolumn{4}{|c|}{ Education (\%) } \\
\hline o & No formal education & 27.6 & 29.9 \\
\hline ○ & $10^{\text {th }}$ Grade & 48.8 & 44.3 \\
\hline ○ & College and Higher & 23.6 & 25.8 \\
\hline Smoke & s (\%) & 22.9 & 27.5 \\
\hline \multicolumn{4}{|c|}{ Type of diabetes (\%) } \\
\hline o & Type 1 & 10.6 & 12.4 \\
\hline o & Type 2 & 89.4 & 87.6 \\
\hline \multicolumn{4}{|c|}{ Blood pressure (\%) } \\
\hline o & Normal & 61.2 & 54.4 \\
\hline O & Hypertensive & 38.8 & 45.6 \\
\hline Insulin & Ise $(\%)$ & 14.1 & 8.3 \\
\hline \multicolumn{4}{|c|}{ Oral hypoglycemic use (\%) } \\
\hline o & Biguanides & 37.6 & 39.4 \\
\hline o & Sulphonylureas & 31.1 & 30.1 \\
\hline o & Meglitinides & 5.9 & 6.5 \\
\hline o & Combinations & 12.5 & 10.7 \\
\hline o & Others & 12.9 & 13.3 \\
\hline \multicolumn{4}{|c|}{ Number of drugs/patient } \\
\hline o & Percent & 1.9 & 2.1 \\
\hline o & Range & $1-3$ & $1-3$ \\
\hline \multicolumn{4}{|c|}{ Fasting blood glucose level (mg/dL) } \\
\hline o & Mean & 175.48 & 178.73 \\
\hline o & Range & 78.4-358.7 & 81.3-333.5 \\
\hline \multicolumn{4}{|c|}{ HbA1c (\%) } \\
\hline o & Mean & 8.54 & 8.51 \\
\hline$\circ$ & Range & $6.1-11.3$ & $5.9-12.6$ \\
\hline
\end{tabular}

physician should work collaboratively in management of diabetic patients.

In this study there was significant increase in medication adherence rates and disease related knowledge in the intervention group. Increase in disease- related knowledge can improve the medication adherence rates as seen in this study. Patients who were in direct contact with the pharmacist showed better preventive care attributes as required by the management guidelines [12]. The present study has demonstrated that increase in self-monitoring of blood glucose levels may improve glycemic control but this is not in agreement with the results of other studies [13]. It was found that knowledge of $\mathrm{HbA} 1 \mathrm{c}$ is poor among diabetic patients. Improvement in understanding of $\mathrm{HbA1c}$ is directly related with improvement in glycemic control as reported in other studies [14]. The present study also found that increase in knowledge regarding dietary restrictions and exercise resulted in improvement in glycemic control as reported in other interventions studies aimed at increasing exercise combined with dietary restrictions [15]. Smoking can increase risk of diabetes associated complications and mortality [16]. The finding of this study indicated that smoking cessation can be promoted in diabetes patients by the pharmacist's intervention 
Table 2: Comparison of primary outcomes between the groups

\begin{tabular}{|c|c|c|c|c|c|c|c|}
\hline \multirow[t]{2}{*}{ Parameter } & \multicolumn{3}{|c|}{ Control group $(n=170)$} & \multicolumn{3}{|c|}{ Intervention group $(n=178)$} & \multirow[b]{2}{*}{$\begin{array}{l}\text { Difference } \\
\text { between } \\
\text { control \& } \\
\text { Intervention } \\
\text { group (95\% } \\
\text { Cl, P value) }\end{array}$} \\
\hline & 0 month & 5 month & $\begin{array}{l}\text { Difference } \\
\text { from } \\
\text { baseline } \\
\text { Mean } \\
\text { difference } \\
(95 \% \mathrm{Cl}, \mathrm{P} \\
\text { value) }\end{array}$ & 0 month & 5 month & $\begin{array}{l}\text { Difference } \\
\text { from } \\
\text { baseline } \\
\text { (95\% Cl, P } \\
\text { value) }\end{array}$ & \\
\hline BMI & $32.01 \pm 8.08$ & $31.42 \pm 7.31$ & $\begin{array}{l}-0.59 \\
P=0.46\end{array}$ & $31.98 \pm 7.85$ & $29.52 \pm 6.78$ & $\begin{array}{l}-2.46 \\
P=0.002\end{array}$ & $\begin{array}{l}1.87 \\
P=0.014\end{array}$ \\
\hline $\begin{array}{l}\text { Waist } \\
\text { circumference }\end{array}$ & $37.98 \pm 5.17$ & $37.01 \pm 4.52$ & $\begin{array}{l}-0.97 \\
P=0.08\end{array}$ & $37.62 \pm 6.30$ & $35.38 \pm 37.01$ & $\begin{array}{l}-2.24 \\
P=<0.001\end{array}$ & $\begin{array}{l}1.27 \\
P=0.002\end{array}$ \\
\hline $\begin{array}{l}\text { Fasting Blood } \\
\text { Glucose } \\
\text { (mg/dL) }\end{array}$ & $175.48 \pm 60.64$ & $168.17 \pm 53.25$ & $\begin{array}{l}-7.31 \\
P=0.23\end{array}$ & $178.73 \pm 60.89$ & $159.47 \pm 54.17$ & $\begin{array}{l}-19.26 \\
P=0.003\end{array}$ & $\begin{array}{l}11.95 \\
P=0.116\end{array}$ \\
\hline $\mathrm{HbA} 1 \mathrm{c}(\%)$ & $8.54 \pm 1.55$ & $8.08 \pm 1.49$ & $\begin{array}{l}-0.46 \\
P=0.11\end{array}$ & $8.51 \pm 1.62$ & $7.50 \pm 1.26$ & $\begin{array}{l}-1.01 \\
P=<0.001\end{array}$ & $\begin{array}{l}0.43 \\
P=0.112\end{array}$ \\
\hline
\end{tabular}

${ }^{a}$ paired sample t-tests for comparing differences between groups at 0 and 20 weeks; ${ }^{b}$ intervention effects by comparing means of both groups at the end of study

Table 3: Comparison of adherence, disease knowledge and self-care activities between the groups

\begin{tabular}{|c|c|c|c|c|c|c|c|}
\hline \multirow[t]{2}{*}{ Parameter } & \multicolumn{3}{|c|}{ Control group $(n=170)$} & \multicolumn{4}{|c|}{ Intervention group $(n=178)$} \\
\hline & 0 month & 5 month & $\begin{array}{l}\text { Difference } \\
\text { from } \\
\text { baseline } \\
(95 \% \mathrm{Cl}, \mathrm{P} \\
\text { value) }\end{array}$ & 0 month & 5 month & $\begin{array}{l}P \text { value } \\
(95 \% \mathrm{Cl})\end{array}$ & $\begin{array}{l}\text { Difference } \\
\text { between control } \\
\& \text { Intervention } \\
\text { group } \\
\mathrm{P} \text { value }(95 \% \mathrm{Cl})\end{array}$ \\
\hline Compliance & $\begin{array}{l}\text { Yes }=21.2 \% \\
\mathrm{No}=68.8 \%\end{array}$ & $\begin{array}{l}\text { Yes }=35.9 \% \\
\text { No }=64.1 \%\end{array}$ & 0.310 & $\begin{array}{l}\text { Yes }=32.6 \% \\
\text { No }=67.4 \%\end{array}$ & $\begin{array}{l}\text { Yes }=41.6 \% \\
\text { No }=58.4 \%\end{array}$ & 0.052 & 0.003 \\
\hline $\begin{array}{l}\text { Knowledge } \\
\text { regarding sensory } \\
\text { changes }\end{array}$ & $\begin{array}{l}\text { Yes }=8.8 \% \\
\text { No }=91.2 \%\end{array}$ & $\begin{array}{l}\text { Yes }=10.6 \% \\
\mathrm{No}=89.4 \%\end{array}$ & 0.439 & $\begin{array}{l}\text { Yes }=13.5 \% \\
\mathrm{No}=86.5 \%\end{array}$ & $\begin{array}{l}\text { Yes }=24.7 \% \\
\text { No }=75.3 \%\end{array}$ & 0.001 & $<0.001$ \\
\hline $\begin{array}{l}\text { Knowledge } \\
\text { regarding foot care }\end{array}$ & $\begin{array}{l}\text { Yes }=35.9 \% \\
\mathrm{No}=64.1 \%\end{array}$ & $\begin{array}{l}\text { Yes }=38.2 \% \\
\mathrm{No}=61.8 \%\end{array}$ & 0.433 & $\begin{array}{l}\text { Yes }=27.0 \% \\
\mathrm{No}=73.0 \%\end{array}$ & $\begin{array}{l}\text { Yes }=40.4 \% \\
\mathrm{No}=59.6 \%\end{array}$ & 0.012 & 0.748 \\
\hline $\begin{array}{l}\text { Knowledge } \\
\text { regarding self- } \\
\text { monitoring of blood } \\
\text { glucose }\end{array}$ & $\begin{array}{l}\text { Yes }=14.3 \% \\
\mathrm{No}=84.7 \%\end{array}$ & $\begin{array}{l}\text { Yes }=21.8 \% \\
\mathrm{No}=78.2 \%\end{array}$ & 0.131 & $\begin{array}{l}\text { Yes }=15.2 \% \\
\mathrm{No}=84.8 \%\end{array}$ & $\begin{array}{l}\text { Yes }=29.2 \% \\
\mathrm{No}=70.8 \%\end{array}$ & 0.002 & 0.001 \\
\hline $\begin{array}{l}\text { Knowledge } \\
\text { regarding exercise }\end{array}$ & $\begin{array}{l}\text { Yes }=24.7 \% \\
\mathrm{No}=75.3 \%\end{array}$ & $\begin{array}{l}\text { Yes }=31.8 \% \\
\mathrm{No}=68.2 \%\end{array}$ & 0.140 & $\begin{array}{l}\text { Yes }=28.7 \% \\
\mathrm{No}=71.3 \%\end{array}$ & $\begin{array}{l}\text { Yes }=41.6 \% \\
\mathrm{No}=58.4 \%\end{array}$ & 0.011 & $<0.001$ \\
\hline $\begin{array}{l}\text { Knowledge } \\
\text { regarding dietary } \\
\text { restrictions }\end{array}$ & $\begin{array}{l}\text { Yes }=14.1 \% \\
\text { No }=85.9 \%\end{array}$ & $\begin{array}{l}\text { Yes }=21.2 \% \\
\text { No }=78.8 \%\end{array}$ & 0.023 & $\begin{array}{l}\text { Yes }=16.9 \% \\
\text { No }=83.1 \%\end{array}$ & $\begin{array}{l}\text { Yes }=29.8 \% \\
\text { No }=70.2 \%\end{array}$ & 0.001 & 0.117 \\
\hline Smoking & $\begin{array}{l}\text { Yes }=22.9 \% \\
\mathrm{No}=77.1 \%\end{array}$ & $\begin{array}{l}\text { Yes }=21.2 \% \\
\mathrm{No}=78.8 \%\end{array}$ & 0.564 & $\begin{array}{l}\text { Yes }=27.5 \% \\
\mathrm{No}=72.5 \%\end{array}$ & $\begin{array}{l}\text { Yes }=19.1 \% \\
\text { No }=80.9 \%\end{array}$ & 0.019 & 0.491 \\
\hline
\end{tabular}

This study was limited to diabetes patients to evaluate the outcomes of pharmacists' intervention in drug therapy and patient education. Further, this study did not account for the microvascular and macrovascular complications associated with diabetes and the results of intervention on these complications. Patients who were solely on insulin therapy were not included in this study. This study was conducted in patients in only two major hospitals in southern Punjab, and hence it cannot be generalized to the whole diabetes population of Pakistan due to pharmacogenomic variations. Limited biasing may be inherent in the parameters measured on 'yes/no' basis but this effect was minimized by the large group size and patient education. There was no age or sex discrimination.

\section{CONCLUSION}

This study further supports the evidence that pharmacists' led intervention programs for diabetes patients can improve glycemic control, medication adherence and disease related knowledge. It further shows that if physicians and pharmacists work collaboratively for clinical management of diabetes patients, better outcomes can be achieved. Therefore, it is 
helpful to involve pharmacists in the activities of diabetes clinics as it is capabale of reducing diabetes-related morbidity and mortality.

\section{CONFLICT OF INTEREST}

Authors have no conflict of interest to declare.

\section{ACKNOWLEDGEMENT}

The authors are thankful to the managements of Nishter Hospital Multan and DHQ Hospital Layyah, Punjab, Pakistan for their kind cooperation and support.

\section{REFERENCES}

1. World Health Organization. Prevention of diabetes mellitus. Report of a WHO Study Group. Geneva. World Health Organization, 1994; 844.

2. UK Prospective Diabetes Study Group. Intensive bloodglucose control with sulphonylureas or insulin compared with conventional treatment and risk of complications in patients with type 2 diabetes (UKPDS) group. Lancet 1998; 352(9131): 837-853.

3. Haynes RB, Taylor DW, Sackett DL. Adherence in Health Care. Baltimore \& London: Johns Hopkins University Press 1979: xvi-516.

4. Sabate E. Adherence to long-term therapies. In: WHO 2003; Geneva.

5. Cramer JA. A systematic review of adherence with medications for diabetes. Diabetes Care 2004; 27(5): 1218-1224.

6. Borenstein JE, Graber G, Saltiel E, Wallac J, Seonyong $R$, Jacksons $A$. Physician-pharmacist comanagement of hypertension: $A$ randomized, comparative trial. Pharmacotherapy 2003; 23(2): 209-216.

7. Centers for Disease Control and Prevention. National diabetes fact sheet: general information and national estimates on diabetes in the United States,
2007. Atlanta, GA: U.S. Department of Health and Human Services, Centers for Disease Control and Prevention, 2008

8. Shojania KG, Ranji SR, McDonald KM,_Grimshaw JM, Sundaram V, Rushakoff RJ, Owens DK. Effects of quality improvement strategies for type 2 diabetes in glycemic control: $A$ meta-regression analysis. JAMA 2006; 296(4): 427-440.

9. Mehuys E, Van Bortel L, De Bolle L, Van Tongelen I, Annemans L, Remon JP, Giri M. Effectiveness of a community pharmacist intervention in diabetes care: A randomized controlled trial. J Clin Pharm Ther 2011; 36(5): 602-613.

10. Chadha VK. Sample size determination in health studies. NTI Bulletin 2006; (42): 55-62.

11. Farsaei $S$, Sabzghabaee AM, Zargarzadeh AH, Amini M. Effect of pharmacist-led patient education on glycemic control of type 2 diabetics: A randomized controlled trial. J Res Med Sci 2001; 16(1): 43-49.

12. Hammad EA, Yasein N, Tahaineh L, Albsoul-Younes AM. A randomized controlled trial to assess pharmacist- physician collaborative practice in the management of metabolic syndrome in a university medical clinic in Jordan. J Manag Care Pharm 2001; 17(4): 295-303.

13. Padiyara RS, D'Souza JJ, Rihani RS. Clinical pharmacist intervention and the proportion of diabetes patients attaining prevention objectives in a multispecialty medical group. J Manag Care Pharm 2011; 17(6): 456-462.

14. Iqbal $N$, Morgan $C$, Maksoud $H$, Idris I. Improving patient's knowledge on the relationship between $\mathrm{HbA1 \textrm {c }}$ and mean plasma glucose improves glycaemic control among persons with poorly controlled diabetes. Ann Clin Biochem 2008; 45(Pt 5): 504-507.

15. Orozco LJ, Buchleitner AM, Gimenez-Perez G, Roqué I $F M$, Richter B, Mauricio D. Exercise or exercise and diet for preventing type 2 diabetes mellitus. Cochrane Database Syst Rev 2008; (3): CD003054.

16. Clair C, Berlin I, Cornuz J. Smoking, obesity and diabetes: a clinically important interaction. Rev Med Suisse 2011; 30; 7(319): 2338-2340. 